\title{
DRIVERS FOR LOCAL ECONOMIC DEVELOPMENT IN SOUTH AFRICAN MUNICIPALITIES
}

\author{
Gail Denise Parker (PhD) \\ parkergail2003@yahoo.com \\ King Costa $(\mathrm{PhD})$ \\ costak@researchglobal.net
}

\begin{abstract}
Local economic development (LED) within municipalities in South Africa has been viewed as a failing project by many commentators, practitioners and scholars. One of the areas attributed as a causal factor for distrust on efforts related to local economic development is lack of clarity on foundational dynamics and drivers of LED. This study used interpretivist approaches to analyze key theoretical frameworks that provide explanations for challenges related to articulation of drivers for LED. As a theoretical paper authors established rigor through mapping theories to building blocks of a theoretical argument being the what, when, how and why. The central argument of this paper is that while the potential of LED strategies is not disputed and the economic value of land is , the implementation of such strategies does not assist in achieving the intended objectives of poverty alleviation and economic development. The study concluded that while local municipalities are mandated by the Constitution to "promote social and economic development", they will not be able to do this without clear policy guidance; institutional capacity-building; inter-sectoral collaboration; political 'champions' to drive the process; and real empowerment ofthe beneficiaries whom the projects is supposed to assist.
\end{abstract}

Key Words : Local economic development. Theoretical framework, Commonage, Business development, Black economic empowerment, Black economic empowerment 


\section{INTRODUCTION}

\subsection{Principles of economic development}

Local economic development is primarily viewed as a sub-discipline of broader national economic strategic intent. Scholars have argued that the discourse on this discipline starts with observation that concludes the fact that productive activities within a particular sectoral economy are not evenly distributed across space. Out of this theoretical perspective two principles that are inter-related, emerged. These principles deal with the issue of population density for economic outcomes and issues of distance hinderance to exchange (Moller, 2019). In South Africa the concept of local economic development, usually attached to local municipalities, was popularized through the reconstruction and development programme in 1994 as avid by $\mathrm{Nel}$ (1999). In alignment to the theoretical framework named above, Moller (2019) propounded that concentration of population in parrticular spaces has a fundamental effect on the economic outcomes of that space, be it district, region or even a country. The nucleated settlement in terms of the population density principle suggests more intensive transactions that could involve exchange of knowledge commodity through different media applications such as face to face or digital. Furthermore, opportunities for close customersupplier relationships could emmerge suggesting that vigilant identification of emmergence of these opportunities could drive local economic development exponentially (Parker, 2004). The second principle related to distance is likely to provide a barrier to economic knowledge transfer. The importance of this principle may be seen in social deprivation to innovation (Moller, 2019). An illustration of economic innovation could be viewed from the perspective of amalgamation of ideas about shared common knowledge between experts from disciplines. A higher spatial concentration of skills as these provides an opportunity for collaboration with intent to stabilize the economy for common good (Moller, 2019; Nel, 2001; Jacobs, 1970). There are means to overcome the distance, however, this involves infrastructural development to enable exchange between economic participants in trade, skills and services.

Local economic cevelopment has been known within the South African context to feature prominently in urban and rural development strategies. Parker, 2004, illustrated some of the guiding principles of LED being :

- Job creation and poverty alleviation

- Upliftment of previously disadvataged people, including marginalised communities in rural areas

- Community engagement and recognition of existing local structures of leadership such as tribal authorities

- Use of local resources and skills development 
Successful policy design, implementation and outcomes achievement relies solely on clear understanding of the causal effect of Moller's (2019) principles of population density and dispersed spatial arrangements. In view of the above, this study focusses on drivers of local economic development.

\subsection{Inconsistent policy approaches}

There is an apparent lack of agreement between civil society organizations andgovernment institutions regarding the character and thrust that these LED interventions should take (Mawson, 1997). Municipalities get away with the excuse that LED is an unfunded mandate, or that they are struggling with service delivery to the poor and can therefore not fund these LED projects. The fact that there is a lack of clear policy around LED causes local municipalities not to get proper guidance to ensure that their LED interventions achieve their intended goals. According to Nel (2001), national and provincial governments have the obligation to introduce realistic policies accompanied by training and support for the implementers - something which, as in the case of Groblershoop, has definitely not happened.

\subsection{Good intentions with poor implementation}

Another alarming discovery made through the course of the research was the absence of welldeveloped LED strategies in the Northern Cape province's Siyanda District and !Kheis municipality. Although LED has been in existence for the past ten years, the LED strategy in each of these spheres of government is still in the process of being developed. The Northern Cape province started in 1994 to develop a strategy for the province that has been reviewed in 1999 and is now in the process of being 'finalized' in the Growth and DevelopmentStrategy. While these draft strategies do make mention of economic priority areas andidentify areas of potential, there are no projects that have resulted from them. This is an inhibiting situation since local government usually follows the example set by provincial structures. In Groblershoop this is evident in the inability of the local politicians to act on their plans to negotiate with the local wine cellars and co- operatives, for opportunities for black emerging farmers to become members and participants in the lucrative export market. Both the mayor and councilor interviewed made mention of the lack of Black Economic Empowerment (BEE) initiatives in the Oranje River Wine Cellars. This is an area where they as politicians can solicit discussions with the shareholders of this company, however, there has been no action for the past ten years.

\subsection{Too much political interference?}

Another important observation, as made by Dewar (1998), was the misuse of LED interventions 
and funding by local politicians. In her study of LED funding in Minnesota (USA), Dewar found that there was too much political control and interference in LED programmes and projects (Cousins and Kepe, 2004). Politicians want to look good and use the allocation of LED funding for their own electioneering purposes, by channeling money to areas where they can get the greatest political support - and not to the areas with greatest need. In Groblershoop this was, arguably, very much the order of the day. The Beeshoek Trust project, for example, appears to be very successful. The leader of the group also remarked that through the close relationship that they have with both local and provincial politicians, they have managed to solicit the support and funding from government for their project. The danger in this is that those who do not have a political voice or who do not have contacts in these government departments may not get the assistance they so desperately require. In almost all casesthese are the 'poorest of the poor' and therefore the most marginalized. A case inpoint is the Vergenoeg group that farms on municipal commonage. These are very poor people who have little resources. The unfortunate reality is that they get little or no assistance from the municipality, government departments or other non-governmental organizations. A solution to this dilemma is for the rural poor to become empowered so as to speak for themselves andbe able to have their plight put on the political agenda (Cousins, 2000). Hence there is a very big role for non-governmental and community-based organizations to champion the plight of poor, landless rural people. It is very unfortunate, but unless lobby groups continually advocate in the mass media (where the larger citizenry gets to hear about the issue) for land and developmental assistanceto be given to the poor, politicians will continue to "politic" about it with very little happening on the ground.

\section{METHODS}

This study is hinged upon interpretivist philosophy, conceptualized around principles of a theoretical paper. A theoretical paper may be defined as a procedural approach to theory development and equally advancement of currently known theoretical perspectives using logic and facts to propound conclusions (Zhou, et al., 2017). It focusses on what is considered as building blocks of theory made up of variables and concepts that provide a causal meaning for a particular phenomenon (Whetten, 1989).

A theory is made up of four critical components commonly known as what, when, how and why. In this study the focus was on what constitutes local economic drivers. The second part of this theoretical paper looks at the principle of when. This principle is cognisant of timebased events that affect application of theory within the balance of other components. In terms of this study economic drivers ae influenced by events such as the principle of population density and the principle of dispersed populations as postulated by (Moller, 2019). The fourth building block that informs this theoretical paper is the how part. This principle 
within this study is important as it establishes issues related to causality and correlation between variables. It is through this principle that the study variables are operationalized and the procedural activities and steps that are taken to explicate the phenomenon are considered (Mintzberg, 2005). The last level of a theoretical study focusses on the rationale or reason behind the theory. (Whetten, 1989). Justification and reasoning behind factorial significance within the context of social, economic and psychological importance as a resolve to a prevailing problem are established. This interrogation culminates in the establishment of theory significance and why it should be applied within the discourse for drivers of local economic development.

The objective of a theoretical paper is to provide a theoretical contribution to solve a prevailing problem or phenomenon (Corley \& Gioia, 2011).

\section{FINDINGS/DISCUSSION}

\subsection{Municipal land and local economic development}

\subsubsection{The burden of commonage}

Land has been both a highly emotive and valuable commodity for African people (Shackleton, et al, 2000) for centuries. This is still the case for many people in the Northern Cape province. The poor, as well as very wealthy, still rely on land-based economic activities to make a living. For this reason, when provincial and local government institutions develop economic development strategies, land is naturallyan important element in these strategies. When the 'new' government assumed powerin 1994, the Northern Cape provincial government and the province's municipalities "inherited vast tracts of land purchased from farmers as early as the mid-1800s," (Benseler, 2002:1). Municipalities leased these farms to commercial farmers on a tender or auction basis. Commonages were therefore a valuable resource to themunicipality. They provided a steady flow of income for the municipality and in addition, the responsibility of maintenance and land use management was not really aconcern.

With the advent of the new democratic State, this situation has changed.Municipalities now have to lease these pieces of land to poor subsistent farmers who cannot necessarily afford to pay market related rentals. They are also not able to manage and maintain the farms to the degree that commercial farmers once did. Municipalities complain that they are now saddled with the added responsibilities of management, administration, facilitation, infrastructure repair, monitoring of the land use and the conservation of the grazing. No institutional arrangements are made to equip municipalities to deal with any of these responsibilities. Commonage management becomes an ad-hoc responsibility of municipal officials working in, sometimes, unrelated sections in the municipality (Benseler, 2002). The establishment of special land management units is a sine qua non for municipalities that own large pieces of commonage land. Municipalities will not be able to manage their commonage land in an economically 
sustainable manner if 'in-house' capacityis not built. The departments of Land Affairs and Agriculture, while they are important partners, are not able to do this.

\subsubsection{Underestimation of the economic value of I and}

Municipal officials and politicians fall in the trap of under-valuing land-based livelihoods. The fact that commercial farmers in the area are very successful in exporting grapes to Europe and Japan; and that they boast the largest abattoir in Africa and plan to expand their export markets to other parts of the world, should be proof enough that there is merit in land-based livelihoods. However, when the IDP of !Kheis municipality is examined, no clear plans and strategies of developing this sector is evident.

\subsubsection{Neglect of natural resources}

It is common practice in many municipalities that communal land is overgrazed; infrastructure is vandalized; and land-use management leaves room for improvement (Benseler, 2002). While there could be various reasons for this inability of the municipality to manage commonages properly (e.g. lack of staff, etc.), the attitude of municipal officials towards commonages and the lack of confidence in the ability of the poor to engage in agricultural production for the market is largely to blame. Andrew et al, (2003:16) concurs and stresses further that "the low value accorded by state agencies to natural resources in people's livelihoods means that they are not accounted for in development plans and projects. Until planners and policy makers (in this case municipal officials) come to appreciate the importance of natural resources to rural people, rural (economic) reform will always fall short of meeting the needs of the very sector and people it is supposed to support".

\subsubsection{Neglect of social aspects of business development}

The second case study illustrates a classical example where a group of unrelated people beneficiaries of various state grants - were pooled together in a group in order to start a business venture. This was not a group of people who came together because of a shared vision and common ideals. Rather they were 'artificially' made into a 'cohesive' group by government officials who wanted to start a food garden project. This group was given a business plan (which they did not recall existed) and was expected to run a successful business venture. The project obviously failed, but it serves as a good example of how implementers of LED projects blatantly disregard the social aspects of businessdevelopment.

This scenario sketched above is very much what happened in many land reform projects throughout South Africa. With the inception of the Land Redistributionprogramme in 1994, the programme was largely based upon the provision of SLAG, which consisted a R16 000 
grant to qualifying individuals. Due to expensive land prices, land reform beneficiaries were compelled to pool their money together inorder to purchase the land (Jacobs, et al, 2003). These were often unrelated people, who at times did not even live in the same part of town. This resulted in heightened tensions because, "rather than building on existing practices and institutions...land reform projects often imposed unfamiliar proposals and new responsibilities on groups with diverse interests and meager resources", groups experienced tension, conflict and projects finally failed (Andrew, 2003:3). It may be true that not all rural poor people want land for commercial reasons, but when local municipalities develop land-based LED projects for the economic advancement of the poor they should refrain from a "rent-a-crowd" approach.

\section{Conclusion}

This paper attempted to extract some key arguments and observations that have emerged from literature regarding the potential of local economic development strategies to stimulate economic growth in rural municipalities. The central argument of this paper is that while the potential of LED strategies is not disputed and the economic value of land is appreciated, the implementation of such strategies does not assist in achieving the intended objectives of poverty alleviation and economic development.

The study concludes that while local municipalities are mandated by the Constitution to "promote social and economic development", they will not be able to do this without clear policy guidance; institutional capacity-building; inter-sectoral collaboration; political 'champions' to drive the process; and real empowerment ofthe beneficiaries whom the projects is supposed to assist.

As a final word, the authors concur with Kepe and Cousins (2002:2), who argue that "although land reform will only be effective if embedded within a broader programme to restructure the agrarian economy, (this) will not lead to significant reduction in rural poverty without a redistribution of political and economic power in favor of the poor. International experience has shown that elites tend to capture the benefits of land reform unless there are decisive shifts in power relations. It is clear that agrarian restructuring (and land-based local economic development) will only be realized through struggle. 


\section{References}

Andrew, M., Schakelton, C. \& Ainslie, A., 2003. Land use and Rural Livelihoods : Have they been enhanced through Land Reform?. Policy Brief, pp. 1 - 4.

Benseler, A., 2002. Municipal Commonage Administration: Can the New-Look Municipalities Promote Emergent Farming?, Bloemfontein: HSRC .

Corley, K. \& Gioia, D., 2011. Builing Theory About Theory Building: What Constitutes a Theoretica Contribution?. Academy of Management Review, 36(1), pp. 12 - 32.

Cousins, B., 2000. At the Crossroads: Land and Agrarian Reform in South Africa into the 21 st Century, Cape Town/Johannesburg: Programme for Land and Agrarian Studies, University of the Western Cape/ National Land Committee.

Cousins, B. \& Kepe, T., 2004. Decentralization when Land and Resources Resource Rights are Deeply Contested: A Case Study of the Mkambati Eco-tourism Project on ythe Wild Coast of South Africa. European Journal of Development Research, 16(1), pp. 41 - 54.

Dewar, M., 1998. Why State and Local Economic Development Programmes Cause so Little Economic Development. Ann Abor: University of Michigan .

Jacobs, J., 1970. The Economy of Cities. London: Johnathan Cape.

Jacobs, P., Lahiff, E. \& Hall, R., 2003. Land Redistribution. Evaluating Land and Agrarian Reform in South Africa. Cape Town, Programme for Land and Agrarian Studies.

Kepe, T. \& Cousins, B., 2002. Radical Land Reform is Key to Sustainable Rural Development in South Africa. Policy Brief, Volume 3.

Mawson, J., 1997. New Labour and the English Regions: A missed opportunity?. Local Economy, 12(3), pp. 192 - 202.

Mintzberg, H., 2005. Developing theory about the development of theory. In: K. Smith \& M. Hitt, eds. Great Minds in Management: The Process of Theory Development. Oxford: Oxford University Press, pp. 355 - 372.

Moller, J., 2019. Conceptual Framework, Theory and Development. In: P. Futo, ed. Contemporary Drivers of Local Develooment. Maribor: Lex Localis, pp. 24 - 99 .

Nel, E., 1999. Regional and Local Economic Development in South Africa. Aldershot: Ashgate Publishing.

Nel, E., 2001. Local Economic Development: A Review and Assessment of its Current Status in South Africa. Urban Studies, 38(7), pp. 1003 - 1024.

Parker, G., 2004. THE CHALLENGE OF SUSTAINABLE LAND-BASED LOCAL ECONOMIC DEVELOPMENT IN POOR COMMUNITIES OF SOUTH AFRICA: THE CASE OF GROBLERSHOOP, NORTHERN CAPE, Cape Town: University of the Western Cape.

Shackleton, S., Schakelton, C. \& Cousins, B., 2000. Re-valuing the Communal Lands of Southern 
Africa: New Understandings of Rural Livelihoods. ODI Natural Resources Perspectives, Volume 62, pp. 1 - 4 .

Whetten, D., 1989. WHAT CONSTITUES A THEORETICAL CONTRIBUTION?. Academy of Management Review, 14(4), pp. 490 -495.

Zhou, J. et al., 2017. What is Theoretical Contribution? A Narrative Review. Sarhad Journal of Management Sciences, 3(2), pp. 261 - 271. 